\title{
ANALISIS MOTIVASI BELAJAR SISWA PADA PEMBELAJARAN IPS DI KELAS VIII MTS MUJAHIDIN PONTIANAK TAHUN AJARAN 2017/2018
}

\author{
Emusti Rivasintha Marjito ${ }^{1}$, Nurhalipah ${ }^{2}$ \\ ${ }^{1,2}$ Program Studi Pendidikan Sejarah \\ Fakultas Ilmu Pendidikan dan Pengetahuan Sosial IKIP PGRI Pontianak \\ Jalan Ampera Nomor 88 Pontianak - 78116, Telepon (0561) 748219 Fax. (0561) 589855 \\ ${ }^{1}$ Alamat e-mail: $\underline{\text { sintha_160111@yahoo.co.id }}$
}

\begin{abstract}
Abstrak
Penelitian ini bertujuan untuk mengetahui motivasi belajar siswa pada mata pelajaran IPS di kelas VIII MTs Mujahidin Pontianak. Tujuan khusus dari penelitian ini adalah untuk mengetahui : 1). Bagaimanakah pembelajaran IPS di kelas VIII MTs Mujahidin Pontianak 2). Bagaimanakah motivasi belajar siswa pada mata pelajaran IPS dikelas VIII MTs Mujahidin Pontianak 3). Faktor-faktor apa saja yang mempengaruhi motivasi belajar siswa pada mata pelajaran IPS dikelas VIII MTs Mujahidin Pontianak. Metode penelitian yang digunakan adalah metode penelitian kualitatif. Teknik pengumpulan datanya berupa teknik observasi langsung, wawancara dan dokumentasi. Faktor-faktor yang mempengaruhi motivasi belajar siswa itu ada dua yaitu faktor internal dan eksternal ditandai dengan pendapat guru mata pelajaran IPS faktor internal itu merupakan faktor yang berasal dari dalam diri siswa karena dengan adanya bakat maka sikap yang ditunjukkan siswa terhadap belajar akan muncul dengan sendirinya, sedangkan faktor eksternal yang mempengaruhi motivasi belajar siswa yaitu dari guru, media, metode dan waktu.
\end{abstract}

Kata Kunci: Motivasi Belajar, Pembelajaran IPS, Pontianak

\begin{abstract}
This research aims to determine student learning motivation in the subjects of social studies in the class VIII MTS Mujahidin Pontianak. Specific objectives in this research are to knowing: 1). how social science applied in class VIII MTs Mujahidin Pontianak 2). How student's motivation about social science applied in class VIII MTs Mujahidin Pontianak 3). What are the factors that affect student's motivation on social science applied in class VIII MTs Mujahidin Pontianak. The research method used is qualitative research methods. Data collection techniques are in the form of direct observation techniques, interviews and documentation. There are two factors that influence student learning motivation, namely internal and external factors characterized by the opinion of the social science teacher's internal factors that are factors that come from within the student because with the talent the attitude shown by students towards learning will emerge automatically. While external factors that influence student motivation are from the teacher, media, method and time.
\end{abstract}

Keywords: Learning motivation, Social science learning, Pontianak.

\section{PENDAHULUAN}

Sekolah sebagai salah satu lembaga pendidikan formal merupakan lingkungan hidup kedua sesudah rumah di mana anak didik sekian jam setiap saat setiap hari mengisi hidupnya. Dalam konteks kehidupan berbangsa dan 
bernegaran pendidikan penting bagi kita. Melalui pendidikan kita dapat menemukan jati diri kita sebagai manusia yang sesungguhnya. Pendidikan dirancang untuk membentuk manusia yang cerdas, berkepribadian, bertanggung jawab, berakhlak mulia, memiliki wawasan yang luas, serta beriman dan bertaqwa Allah Swt.

Menurut Suryani dan Agung, (2012:1) pembelajaran pada dasarnya adalah suatu kegitan yang bernilai edukatif. Nilai edukatif mewarnai interaksi yang terjadi antara guru dan peserta didik. Interaksi bernilai edukatif dikarenakan pembelajaran yang dilakukan, diarahkan untuk mencapai tujuan yang telah dirumuskan sebelumnya. Pembelajaran IPS yang dilakukan baik pada pendidikan tinggi tidak menekankan pada aspek teoritis keilmuannya, tetapi aspek praktis dalam mempelajari, dalam menkaji, gejala dan masalah sosial masyarakat, yang bobot dan keluasaannya disesuaikan dengan jenjang pendidikan masing-masing.

Satu diantara indikator yang menunjang tercapainya suatu tujuan pendidikan adalah proses pembelajaran. Karena pembelajaran pada hakikatnya merupaka interaksi peserta didik dengan pendidikan dan sumber belajar pada suatu lingkungan belajar yang meliputi guru dan siswa yang saling bertukar informasi. Pemberian motivasi kepada siswa dalam kegiatan interaksi belajar mengajar merupakan suatu hal yang penting sekali. Motivasi belajar adalah keseluruhan daya pengerak dalam diri siswa untuk melakukan suatu kegiatan yang menimbulkan kegiatan belajar untuk mencapai suatun tujuan tertentu. Adapun tujuan yang akan dicapai dalam hal ini adalah tujuan belajar. Oleh karena itu seorang siswa harus mempunyai motivasi belajar yang tinggi agar tujuan belajar yang hendak ditempuh dapat tercapai dengan baik.

Menurut Sardiman, (2005:73) mengatakan bahwa. "motivasi belajar adalah dalam kegiatan belajar, maka motivasi sebagai keseluruhan daya penggerak di dalam diri siswa yang menimbulkan kegiatan belajar, yang menjamin kelangsungan dari kegiatan belajar dan yang memberikan arah pada kegitan belajar, sehingga tujuan yang dikehendaki oleh subjek belajar itu dapat tercapai. 
Namun permasalahanya adalah tidak semua siswa menyadari bahwa materi pelajaran tersebut penting untuk dipelajhari. Sebagian siswa mengangap bahwa pelajaran IPS hanyalah mata pelajaran yang bersipat formal dan tidak berpengaruh banyak untuk dimanfaatkan nilai-nilainya dalam kehidupan seharihari. Berdasarkan kenyataan dilapangan, harapan yang peneliti ingin capai adalah guru diharapkan dapat menciptakan suasana yang nyaman dalam proses pembelajar mengajar dan bisa mengerti bentuk motivasi seperti apa yang dapat membangkitkan gairah belajar siswa agar dalam memahami mata pelajaran IPS dapat berhasil dengan baik maka peranan guru sangatlah dituntut agar dapat mentranfer ilmu atau menyampaikan materi sebaik mungkin kepada siswa sehingga siswa pun mampu dapat mengerti serta memahami pelajaran tersebut. Sebab keberhasilan dari proses pembelajaran sangat tergantung dari kemampuan guru dalam melaksanakan atau mengemas proses pembelajaran serta memenfaatkan media pembelajaran yang ada karena pada dasarnya seperti apapun tujuan pendidikan yang kita harapkan jika dalam proses pembelajaran tidak berjalan dengan baik maka semuanya akan sia-sia, begitu juga sebaliknya apabila proses pembelajaran tidak dikemas dengan baik maka harapan yang kita ingin kan dalam pencapaian tujuan pendidikan akan sia-sia juga.

\section{METODE}

Metode mempunyai arti yang sangat penting di dalam penelitian. Ilmiah tidaknya suatu penelitin tergantung pada metode penelitian yang dipergunakan. Bila metode penelitian sifatnya ilmiah, maka tidak peduli apa yang diselidiki mineral jiwa, bakteri, masalah sosial, hasilnya bersifat ilmiah juga.Berdasarkan pendapat di atas, metode penelitian yang peneliti gunakan adalah metode deskriptif. Peneliti memilih metode ini karena metode deskriptif menggambarkan keadaan suatu objek secara rinci dan berdasarkan fakta di lapangan. Digunakannya metode deskriptif dalam penelitian ini karena peneliti ingin mengungkapkan data-data atau fakta-fakta apa adanya yang dikumpulkan pada saat penelitian dilakukan, yang berkenaan dengan analisis motivasi belajar siswa 
pada mata pelajaran IPS di kelas VIII MTs Mujahidin Pontianak Tahun Ajaran $2017 / 2018$.

Bentuk penelitian yang tepat dan sesuai dengan metode yang dipilih dan digunakan akan memungkinkan suatu penelitian akan mencapai hasil yang optimal sesuai yang diharapkan. Bentuk penelitian yang dianggap coccok adalah study kasus. Robert K. Yin. (1990:45) mengemukakan: "studi kasus adalah salah satu metode penelitian dalam ilmu sosial".

Teknik pengumpulan data yang peneliti gunakan adalah tiga teknik pengumpulan data, yaitu teknik komunikasi langsung, teknik observasi langsung, dan teknik studi dokumenter/bibliografis. Untuk mendapatkan data yang akurat dilapangan dalam penelitian ini akan menetapkan beberapa alat sebagai pengumpulan data adalah panduan observasi, panduan wawancara dan dokumentasi. Data-data yang telah dikumpulkan dari sumber data tidak semuanya akurat, sehingga dibutuhkan suatu teknik tepat untuk menguji keapsahan data. Untuk menguji data dalam penelitian ini digunakan teknik triangulasi. Teknik tringulasi berarti peneliti menggunakan teknik pengumpulan data yang berbedabeda untuk mendapatkan data dari sumber yang sama, namun dalam penelitian ini hanya digunakan tringulasi data dan tringulasi metode.

Teknik analisis data yang digunakan dalam penelitian ini adalah analisis model interkatif (interactive model of analysis). Menurut Sugiyono (2011:338) dalam model interaktif terdapat tiga komponen analisis, yaitu reduksi data, sajian data dan penarikan kesimpulan, dilakukan dengan bentuk interaktif dengan proses pengumpulan data (data collecting) sebagai suatu siklus.

\section{HASIL DAN PEMBAHASAN}

\section{A. Pembelajaran IPS di Kelas VIII MTs Mujahidin Pontianak}

Hasil penelitian yang telah dilaksanakan menunjukan bahwa perencanaan dalam kegiatan proses belajar mengajar guru banyak mempersiapkan bahan ajaran yang siap digunakan dalam proses belajar mengajar seperti halnya mempersiapkan silabus dan Rencana Program Pembelajaran (RPP). RPP dianggap sangat penting 
karena dalam pelaksanaan nya RPP yang akan menjadi panduan seorang guru dalam penerapan dalam proses belajar mengajar dalam RPP terdapat berbagai macam metode yang digunakan, Metode merupakan salah satu faktor terpenting dalam proses pembelajaran, oleh sebab itu guru dituntut untuk bisa memahami kondisi dan keadaan siswa serta menentukan metode mana yang cocok digunakan. Dalam meningkatkan kualitas belajar mengajar, sebenarnya tidak terlepas dari metode yang digunakan dalam proses belajar mengajar, karena berhasil tidaknya tujuan yang akan dicapai dipengaruhi oleh efektif dan tidaknya proses belajar mengajar.

Hal utama yang harus disiapkan guru sebelum melaksanakan kegiatan pembelajaran adalah menyiapkan perangkat pembelajaran. perangkat pembelajaran meliputi beberapa komponen-komponen yang berhubungan langsung untuk menunjang proses pembelajaran. Berdasarkan hasil penelitian yang dilaksanakan, guru telah merencanakan dengan matang pembelajaran yang dilakukan. Guru telah mempersiapkan dengan matang pembelajaran dengan pembuatan RPP yang mengacu pada kurikulum KTSP. Langkah ini sudah tepat merujuk kepada pendapat Suprihatiningrum (2013:109) yang mengatakan bahwa: “jika tidak direncanakan dengan baik, pembelajaran di kelas di rancang ke dalam perangkat pembelajaran. Salah satunya ialah dengan menyusun RPP yang menggambarkan rencana prosedur dan pengorganisasian pembelajaran untuk mencapai Kompetensi Dasar (KD) yang telah ditetapkan.

Perencanaan pembelajaran yang dilakukan oleh guru IPS di SMP MTs Mujahidin Pontianak yaitu guru menggunakan buku IPS terpadu kurikulum KTSP sebagai sumber belajar di dalam penyusunan program pembelajaran, guru IPS menggunakan acuan Standar Kompetensi (SK) dan Kompetensi Dasar (KD). Guru juga menggunakan buku IPS terpadu untuk menetapkan indikator yang ingin dicapai dalam setiap Kompetensi Dasar (KD) yang menjadi acuan guru. Guru juga menggunakan berbagai media pembelajaran yang disiapkan sendiri oleh guru untuk setiap pembelajaran IPS. Media pembelajaran yang digunakan oleh guru dirasakan sangat bermanfaat dalam membangkitkan motivasi belajar siswa di dalam kelas. Dengan kemampuan guru dalam membangkitkan semangat dan 
motivasi siswa, maka suasana pembelajaran akan terasa menarik dan tidak membosankan sehingga pemahaman akan materi IPS dalam pembelajaran IPS akan lebih baik.

\section{B. Motivasi Belajar Siswa pada Mata Pelajaran IPS di kelas VIII MTs Mujahidin Pontianak}

Motivasi belajar di kelas VIII MTs Mujahidin Pontianak terlihat baik ini di tandai dengan aktifnya siswa dalam kegiatan belajar di kelas seperti bertanya pada materi yang telah lalu mereka berebut untuk menjawab, meskipun tidak semua tetapi lebih banyak yang aktif. Dalam melaksanakan proses pembelajaran IPS di kelas VIII MTs Mujahidin Pontianak guru telah melakukannya dengan baik dan sesuai dengan RPP yang telah dibuat. Adapun yang kurang sesuai antara pelaksanaan dengan perencanaan pembelajaran IPS adalah masalah waktu. Ini disebabkan karena sebelum memulai pembelajaran, guru mempersiapkan terlebih dahulu alat-alat yang digunakan untuk penggunaan media sehingga waktu sedikit terbuang untuk persiapan tersebut. Selain itu, dalam pelaksanaan guru belum menggunakan kurikulum 2013, guru mengajar masih menggunakan kurikulum KTSP.

Proses pembelajran IPS di kelas dibagi menjadi tiga kegiatan yaitu kegiatan pendahuluan, inti, dan penutup. Pada kegiatan pendahuluan, guru mengucapkan salam dan menyapa seluruh murid. Kemudian guru menyuapkan alat yang akan digunakan untuk media pembelajaran dibantu oleh beberapa siswa.Persiapan ini lah yang menyita sedikit waktu yang telah ditentukan. Selain itu guru melanjutkan ke kegiatan inti pembelajaran yaitu guru sedikit menjelaskan kepada siswa tantang materi yang akan diajarkan. Setelah guru menjelaskan, kemudian siswa dipersilahkan mengadakan sesi tanya jawab untuk menambah pemahaman siswa mengenai materi yang disampaikan. Guru sangat menguasai materi IPS yang diajarkan.

Pelaksanaan kegiatan inti ada beberapa siswa yang kurang memperhatikan penjelasan yang disampaikan oleh guru. Selanjutnya kegiatan penutup dengan melakukan refleksi materi yang telah dibahas dengan menarik kesimpulan serta 
dengan memberikan tugas kepada siswa. Setelah itu guru menutup pelajaran dengan mengucapkan salam.Guru melakukan hal-hal yang sesuai dengan apa yang sudah direncanakan. Dalam RPP dicantumkan bahwa evaluasi menggunakan tes dan non tes, yang tidak sesuai adalah evaluasi non tes dimana dalam evaluasi non tes menggunakan observasi yang di dalam pelaksanaannya tidak dilakukan oleh guru, begitu juga dengan lembar pengamatan penilaian sikap tidak sepenuhnya dinilai oleh guru.Kenyataan di lapangan, guru juga menggunakan berbagai metode pengajaran seperti ceramah bervariasi, tanya jawab, diskusi, simulasi, inquiri, observasi/ pengamatan.

\section{Faktor-Faktor yang Mempengaruhi Motivasi Belajar Siswa pada Mata pelajaran IPS di Kelas VIII MTs Mujahidin Pontianak}

Faktor-faktor yang mempengaruhi motivasi belajar siswa itu ada dua yaitu faktor internal dan eksternal yang mana faktor internal itu merupakan faktor internal dan eksternal yang mana faktor internal itu merupakan faktor yang berasal dari dalam diri siswa itu sendiri karena dengan adanya bakat maka sikap yang ditunjukan siswa terhadap belajar akan muncul dengan sendirinya, sedangkan faktor internal yang mempengaruhi motivasi belajar siswa yaitu dari guru, media, metode, dan waktu. Guru memiliki posisi tersedia terhadap siswa sehingga posisi dan peran yang dimainkan tercermin dalam berbagai tingkah laku karena dalam proses belajar mengajar.

Berdasarkan hasil analisis data, faktor yang mengaruhi motivasi belajar siswa yaitu kehadiran guru di dalam kelas. Sarana dan prasarana yang mendukung kegiatan pembelajaran dan dengan pengunaan media pembelajaran juga merupakan salah satu faktor yang mempengaruhi motivasi belajar siswa. Faktor yang dapat mempengaruhi motivasi belajar siswa ada dua faktor yaitu insternal dan eksternal yang mana faktor internal merupakan faktor yang berasal dari dari dalam diri siswa itu sendiri sedangkan eksternal merupakan faktor yang dari luar yang dapat meningkatkan motivasi belajar siswa yaitu melalui guru dan lingkungan sekolah. 
Motivasi memiliki peran yang sangat penting dalam pembelajaran di sekolah. Tanpa ada motivasi siswa akan sedikit mengalami kesulitan di dalam proses belajar mengajar. Maka dari itu motivasi senantiasa akan menentukan intensitas usaha belajar bagi siswa. Motivasi belajar juga merupakan salah satu bagian yang integral dari pencapaian tujuan pembelajaran. Penggunaan motivasi dalam proses pembelajaran bukan saja melengkapi prosedur mengajar, melainkan juga menjadi faktor yang menentukan pengajaran efektif. Dengan demikian, penggunaan motivasi sangat esensial dalam proses dalam proses pembelajaran, sehingga siswa harus mempunyai motivasi untuk mengikuti kegiatan belajar yang akan berlangsung, maupun yang sedang berlangsung.

\section{SIMPULAN}

Pembelajaran IPS di kelas VIII MTs Mujahidin Pontianak dilakukan oleh guru sudah sangat baik. Guru sebelum memulai proses belajar mengajar telah mempersiapkan dirinya dan semua bahan ajar dengan matang sesuai dengan materi pelajaran IPS yang akan disampaikan pada siswa-siswi di kelas.

Motivasi belajar siswa di kelas VIII MTs Mujahidin Pontianak sudah tergolong cukup baik dan seusai dengan perangkat serta materi pelajaran, dimana semua fasilitas sangat menunjang seperti perangkat pembelajaran, media dan sarana sudah sangat memadai. Pada kegiatan awal pembelajaran yang dilakukan oleh guru sudah sesuai dengan langkah-langkah. Hanya saja terkadang guru tidak berurutan dalam melaksanakan kegiatan awal. Pada kegiatan inti pembelajaran yang dilakukan oleh guru sudah sesuai dengan langkah-langkah rencana pelaksanaan pembelajaran (RPP). Dengan terpenuhinya fasilitas di sekolah dan semua yang menjadi kebutuh siswa-siswi serta pembelajaran yang menarik, dapat menimbulkan motivasi siswa-siswi dalam pembelajaran di MTs Mujahidin Pontianak.

Faktor yang mempengaruhi motivasi belajar siswa di kelas VIII MTs Mujahidin Pontianak terdiri dari dua faktor yaitu internal yang berasal dari dalam diri siswa itu sendiri karena dengan adanya bakat maka sikap yang ditunjukkan siswa terhadap belajar akan muncul dengan sendirinya. Sedangkan faktor 
eksternal yang mempengaruhi motivasi belajar siswa yaitu dari guru, media, metode dan waktu. Kegiatan dalam proses pembelajaran yang terjadi di MTs Mujahidin Pontianak menggunakan berbagai langkah stratergi, metode dan media dari dalam proses belajar mengajar. Berbagai macam cara ini lah yang digunakan dalam proses belajar mengajar yang digunakan guru mata pelajaran IPS terpadu di kelas VIII MTs Mujahidin Pontianak agar dapat meningkatkan motivasi siswa untuk berpikir kritis dan kreatif.

\section{DAFTAR PUSTAKA}

Agung, L. dan Suryani, N. (2012). Strategi Belajar Mengajar. Yogyakarta: Ombak.

Aunurrahman. (2012). Belajar dan Pembelajaran. Bandung: Alfabeta.

Diamyati dan Mudjiono. (2009). Belajar dan Pembelajaran. Jakarta: Reneka Cipta.

Hamdani. (2011). Strategi Belajar Mengajar. Bandung: CV Pustaka Setia.

Hamzah. (2016). Teori Motivasi dan Pengukurannya Analisis di Bidang Pendidikan. Jakarta: Bumi Angkasa.

Nawawi, H. (2012). Metode Penelitian Bidang Sosial. Yogyakarya: Gajah Mada University press.

Sapriya. (2009) Pendidikan IPS. Bandung: PT. Remaja Rosdakarya.

Sadirman. (2011). Ineraksi dan Motivasi Belajar Mengajar. PT. Raja Grafindo: Persada.

Subana dan Sudrajat. (2005). Dasar-Dasar Penelitian Ilmiah. Bandung: Pustaka Setia.

Sugiyono. (2010). Memahami Penelitian Kualitatif. Bandung: Alfabeta.

Sugiyono. (2013). Metode penelitian pendidikan pendekatan kuntitatif,kualitatif dan $R \& D$. Bandung: Alfabeta.

Sujarwarni, V. Wiratna. (2014). Metodelogi penelitian. Yogyakarta: Pustaka Barures 
SOSIAL HORIZON: Jurnal Pendidikan Sosial, Vol. 5, No. 1, Juni 2018

Sutopo, H.B. (2012). Metode Penelitian Kualitatif. Surakarta: Universitas Sebelas Maret.

Slameto. (2015). Belajar dan Faktor-Faktor yang Mempengaruhi. Jakarta: Renika Cipta

Soemanto, W. (2003). Psikologi Pendidikan. Jakarta: PT. Rineka Cipta.

Oemar Hamalik. (2015). Proses Belajar Mengajar. Jakarta: PT Bumi Aksara.

Trianto. (2010). Model Pembelajaran Terpadu Konsep Strategi dan Implementasi Dalam Kurikulum Tingkat Satuan Pendidikan (KTSP). Jakarta: Bumi Aksara.

Zuldafrial. (2012). Strategi Belajar Mengajar. Surakarta: Cakrawala Media. 